\title{
Ectoparasites infesting animals living in close contact with human beings: a real trouble for One Health perspective?
}

\author{
[Ectoparasitos infestando animais que vivem em contato próximo com seres humanos: \\ um problema real para a perspectiva Saúde Única?] \\ J.C.P. Oliveira ${ }^{1}$, W.S.M. Oliveira ${ }^{2}$, R.S. Brito ${ }^{2}$, T.A.R.F. Lima ${ }^{3}$, \\ A. Giannelli ${ }^{4}$, G.A. Carvalho ${ }^{2}$, R.A.N. Ramos ${ }^{2}$ \\ ${ }^{1}$ Aluna de pós-graduação - Universidade Federal Rural de Pernambuco - Recife, PE \\ ${ }^{2}$ Universidade Federal do Agreste de Pernambuco, Garanhuns, PE \\ ${ }^{3}$ Universidade Federal de Pernambuco, Recife, PE \\ ${ }^{4}$ Vaxinano - Faculté de Medecine - Pole recherche - Lille, França
}

\begin{abstract}
The number of domestic animals living with human beings is rapidly increasing in parallel with an enhanced risk of transmission of their parasites and the pathogens they might carry. The aim of this study was to assess the occurrence of hematophagous arthropods infesting domestic animals from Northeastern Brazil and to remark the implications of their occurrence on the epidemiology and control of selected veterinary and human diseases. From January 2017 to April 2019, ectoparasites infesting domestic cats, dogs and horses were collected for their respective hosts and identified. Overall, ectoparasites were sampled from 86 domestic animals, living in different anthropic settings. A total of 401 specimens (344 ticks and 57 fleas) were collected from different hosts [i.e., 10 (2.49\%), 96 (23.94\%) and 295 (73.57\%) from cats, dogs and horses, respectively]. Two flea (i.e., Ctenocephalides canis and Ctenocephalides felis) and 5 tick species (i.e., Amblyomma ovale, Amblyomma sculptum, Dermacentor nitens, Rhipicephalus microplus and Rhipicephalus sanguineus sensu lato) were identified. This study provides data on the ectoparasite fauna infesting domestic animals from Northeastern Brazil. The diagnosis and treatment of these parasites should not be underestimated, considering the role that hematophagous arthropods display as vectors of pathogens of medical and veterinary concern.
\end{abstract}

Keywords: dog, cat, flea, horse, tick

\section{RESUMO}

O número de animais domésticos infestados por ectoparasitos vivendo em estreito contato com seres humanos está aumentando, elevando o risco de infecção pelos patógenos transmitidos por vetores. Objetivou-se neste estudo avaliar a ocorrência de ectoparasitos infestando animais do nordeste do Brasil e discutir as implicações desse parasitismo na epidemiologia e no controle de doenças de importância médico-veterinária. De janeiro de 2017 a abril de 2019, artrópodes foram coletados de gatos, cães e cavalos, e identificados morfologicamente. Ectoparasitos foram removidos de 86 animais infestados provenientes de áreas urbanas e rurais. Foram identificados 401 espécimes (344 carrapatos e 57 pulgas) coletados de diferentes hospedeiros (10 (2,49\%), 96 (23,94\%) e 295 (73,57\%) de gatos, cães e cavalos, respectivamente. Duas espécies de pulgas (Ctenocephalides canis e Ctenocephalides felis) e cinco espécies de carrapatos (Amblyomma ovale, Amblyomma sculptum, Dermacentornitens, Rhipicephalus microplus e Rhipicephalus sanguineus sensu lato) foram identificadas. Este estudo fornece informações sobre a ectofauna de animais domésticos do nordeste do Brasil. Portanto, o diagnóstico e o tratamento desses parasitos não devem ser subestimados, considerando que os artrópodes aqui relatados podem veicular patógenos de importância médico-veterinária.

Palavras-chave: cão, gato, pulga, cavalo, carrapato

Recebido em 12 de junho de 2020

Aceito em 1 de setembro de 2020

*Autor para correspondência (corresponding author)

E-mail: rafael.ramos@ufape.edu.br 


\section{INTRODUCTION}

Over the last decades, the number of domestic animals living alongside human beings has undoubtedly increased (Esch and Petersen, 2013). Dogs and cats represent the most widespread pets worldwide in both urban and rural settings, acquiring a great social importance in our daily modernity and society (Krause-Parello, 2012). Similarly, horses have also established a deeper relationship with humans, not just relying to their historic use in military operations (Digard, 2012). Although the importance of these domestic animals on several facets of the modern human society is indisputable, this connection also encourages the risk of transmission of zoonotic pathogens (Esch and Petersen, 2013).

Among ectoparasites, hematophagous arthropods, including ticks and fleas, are able to parasitize a wide number of vertebrate hosts including domestic animals, wildlife and humans (Mencke, 2013). Ectoparasites show a variegated geographical distribution, mainly influenced by the environmental and biotic factors influencing their epidemiology (Dantas-Torres and Otranto, 2016). For instance, in Brazil, more than 60 species of ticks and fleas have been reported (Zimmermann et al., 2018; Linardi, 2017) and currently considered as vectors of at least 24 pathogens of zoonotic concern, causing borreliosis, rickettsiosis and plague (Linardi, 2017; Dantas-Torres and Otranto, 2016). Interestingly, several vector-borne diseases known to occur only in rural or wild environments (Moraes-Filho, 2017), are now diagnosed also in urban areas (Gonçalves et al., 2015) as a likely consequence of the high degree of adaptability some ectoparasite species display (Limongi et al., 2013; Kumsa et al., 2019). In this context, anthropic actions, such as animal trading, farming, or transport, have contributed to the expansions of several ectoparasites alongside the vector-borne pathogens they carry (Dantas-Torres and Otranto, 2016).

Nowadays some species are in a so-called urbanization process, with a dramatic impact of the circulation of pathogens (Trotta et al., 2012), requiring a general reconsideration on the modalities these diseases should be managed. With a One Health approach, for instance, animal, human and environmental health are considered as a unique entity, connected among themselves (Cunningham et al., 2017). It has been demonstrated for instance that the presence of dogs seropositive to Lyme disease is a risk factor for the occurrence of the human infection by Borrelia spp. (Liu et al., 2019). Similarly, the presence of dogs and horses exposed to Rickettsia spp. favor the occurrence of Spotted Fever (Pacheco et al., 2011). The aim of this study was to assess the occurrence of ectoparasites infesting cats, dogs and horses living alongside humans in an area of North-eastern Brazil and to report on the implications of these findings on the epidemiology of zoonotic ectoparasite.

\section{MATERIAL AND METHODS}

The study was conducted in 14 different municipalities of the state of Pernambuco, Northeastern Brazil (Figure 1). The area is featured by an altitude of $842 \mathrm{~m}$ above sea level (asl), semiarid climate with mean annual temperature of 22 ${ }^{\circ} \mathrm{C}$ (from $17{ }^{\circ} \mathrm{C}$ to $30{ }^{\circ} \mathrm{C}$ ), mean rainfall of 147 (from $25 \mathrm{~mm}$ to $295 \mathrm{~mm}$ ) and relative air humidity of $80 \%$.

The Ethics Committee for Animal Experimentation (ECAE) of Universidade Federal Rural de Pernambuco approved the procedures herein performed on animals (license number: 94/2018). From January 2017 to April 2019, domiciled cats, dogs and horses were examined for the presence of ticks, fleas and lice. Animals were sampled by convenience irrespective of their gender, age or breed, and data recorded in individual clinical charts. Animals were carefully inspected for the presence of arthropods over 5 minutes through the examination of the following body regions: head, ears, breast-neck, thorax, abdomen, fore and hind limbs, axilla, tail, inguinal area and, only for cats and dogs, inter-digital areas (Dantas-Torres et al., 2013). All specimens collected were stored in plastic tubes containing $70 \%$ ethanol for morphological analysis. Ectoparasites were separated according to their gender and stage, being morphologically identified at species level using dichotomous keys (Aragão and Fonseca, 1961; Linardi and Guimarães, 2000; Guimarães et al., 2001). 


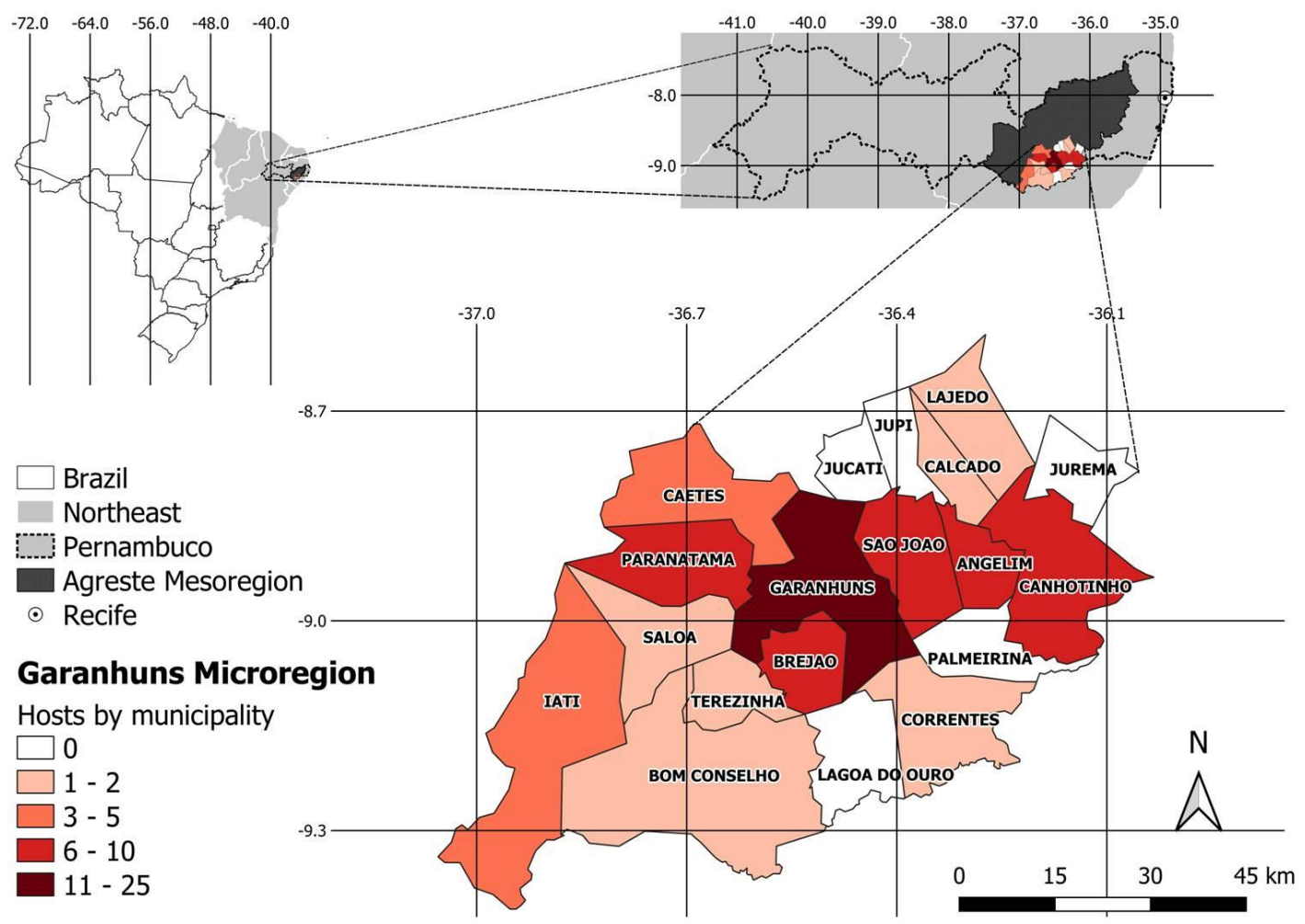

Figure 1. Distribution of the sampled animals (i.e., hosts) according to the municipalities of the Microregion of Garanhuns, state of Pernambuco, Northeastern Brazil.

A descriptive analysis was performed to obtain absolute and relative frequencies. The Friedman test was used to compare the difference between genders of ectoparasites (i.e., males vs females). In addition, the difference of ectoparasites collected in rural and urban areas were analyzed using the Chi-square $\left(\chi^{2}\right)$ test. No statistical analysis was performed to assess the difference among ectoparasites sourced from dogs, cats and horses due to the great difference on the number of specimens collected in each vertebrate host. The significance level was set up at 5\%. All analyses were carried out using the statistical software BioEstat version 5.0 (Ayres et al., 2007).

The mean intensity was calculated based on the formula proposed by Bush et al. (1997). Maps were constructed using the Quantum Geographic Information System (QGIS 3.2 Zanzibar), and the optimization Jenks method was used to categorize the data (Jenks and Caspall, 1971).

\section{RESULTS}

A total of 86 domestic animals (i.e., 8 cats; 22 dogs and 56 horses) infested by ectoparasites and from urban $(n=37)$ and rural $(n=49)$ areas were included in this study (Table 1).

401 ectoparasite specimens (i.e., 344 ticks and 57 fleas; $\chi^{2}=206.038 ; \mathrm{P}=0.0000$ ) were collected, with the majority of arthropods sampled from horses (i.e., 295 individuals, $73.57 \%$ ) followed by dogs $(10,2.49 \%)$ and cats $(96,23.94 \%)$, respectively (Table 2). Cats were parasitized exclusively by fleas, horses only by ticks and dogs were co-infested by both ectoparasites. No lice were detected. 
Oliveira et al.

Table 1. Frequency and mean intensity of infestation by flea and tick species collected on cats, dogs and horses

\begin{tabular}{|c|c|c|c|c|c|c|c|c|c|}
\hline Animal & & & Cat & & & Dog & & & Iorse \\
\hline Ectoparasites & $\mathrm{N}$ & $\%$ & $\begin{array}{l}\text { Mean intensity } \\
\text { (min. - max.) }\end{array}$ & $\mathrm{N}$ & $\%$ & $\begin{array}{l}\text { Mean intensity } \\
\text { (min. - max.) }\end{array}$ & $\mathrm{N}$ & $\%$ & $\begin{array}{c}\text { Mean } \\
\text { intensity } \\
(\min .-\max .)\end{array}$ \\
\hline \multicolumn{10}{|l|}{ Fleas } \\
\hline Ctenocephalides canis & 0 & 0 & 0 & 3 & 13.64 & $1.66(1-3)$ & 0 & 0 & 0 \\
\hline Ctenocephalides felis & 8 & 100 & $1.25(1-2)$ & 19 & 86.36 & $2.21(1-3)$ & 0 & 0 & 0 \\
\hline \multicolumn{10}{|l|}{ Ticks } \\
\hline Amblyomma ovale & 0 & 0 & 0 & 1 & 100 & $1(1)$ & 0 & 0 & 0 \\
\hline Amblyomma sculptum & 0 & 0 & 0 & 0 & 0 & 0 & 3 & 5.36 & $17.33(1-24)$ \\
\hline Dermacentor nitens & 0 & 0 & 0 & 0 & 0 & 0 & 50 & 89.29 & $4.68(1-9)$ \\
\hline Rhipicephalus microplus & 0 & 0 & 0 & 0 & 0 & 0 & 3 & 5.36 & $3(2-4)$ \\
\hline $\begin{array}{l}\text { Rhipicephalus sanguineus } \\
\text { s.1. }\end{array}$ & 0 & 0 & 0 & 21 & 95.45 & $2.28(1-3)$ & 0 & 0 & 0 \\
\hline
\end{tabular}

Table 2. Number of domestic animals sampled, their origin and ectoparasites collected shown per stage/gender

\begin{tabular}{|c|c|c|c|c|c|}
\hline Host (n) & $\begin{array}{l}\text { Host per origin } \\
\text { (n) }\end{array}$ & Ectoparasites (n) & $\begin{array}{l}\text { Nymphs } \\
\text { (ticks) }\end{array}$ & Male & Female \\
\hline \multirow{2}{*}{ Cat (8) } & Rural (3) & Ctenocephalides felis (3) & - & 0 & 3 \\
\hline & Urban (5) & Ctenocephalides felis (7) & - & 2 & 5 \\
\hline \multirow{6}{*}{$\operatorname{Dog}(22)$} & \multirow{2}{*}{ Rural (6) } & Ctenocephalides felis (8) & - & 0 & 8 \\
\hline & & Rhipicephalus sanguineus s.1. (31) & 0 & 13 & 15 \\
\hline & \multirow{4}{*}{ Urban (16) } & Ctenocephalides canis (5) & - & 5 & 0 \\
\hline & & Ctenocephalides felis (34) & - & 9 & 25 \\
\hline & & Amblyomma ovale (1) & 0 & 0 & 1 \\
\hline & & Rhipicephalus sanguineus s.1. (17) & 2 & 3 & 12 \\
\hline \multirow{4}{*}{ Horse (56) } & \multirow{3}{*}{ Rural (40) } & Amblyomma sculptum (52) & 3 & 15 & 34 \\
\hline & & Dermacentor nitens (170) & 29 & 27 & 114 \\
\hline & & Rhipicephalus microplus (9) & 0 & 2 & 7 \\
\hline & Urban (16) & Dermacentor nitens (64) & 9 & 20 & 35 \\
\hline
\end{tabular}

The majority of fleas were females $(71.93 \%)$ followed by males $(28.07 \%) \quad(\mathrm{Fr}=3.0000$; $\mathrm{P}=0.0833$ ), whereas $63.37 \%$ ticks were females and $23.26 \%$ males $(\mathrm{Fr}=4.0000 ; \mathrm{P}=0.0455)$. Most of ticks collected were adults (86.63\%), with only a few nymphs detected (13.37\%). No larval stages were found. Dogs and cats were the main animals in urban area while horse lived in rural zones. Accordingly, fleas predominated in urban areas while ticks in rural zones $\left(\chi^{2}=56.942 ; \mathrm{P}=0.0000\right)$. The distribution of ectoparasites and respective hosts according to the municipality is summarized in Figure 2. The municipalities in color were sampled for this study.

\section{DISCUSSION}

This survey reports on the prevalence of ectoparasitic infestation in domestic animals from northeastern Brazil. Results indicate that domestic cats, dogs and horses are exposed to two species of fleas (C. canis and $C$. felis) and five species of ticks (A. ovale, A. sculptum, D. nitens, $R$. microplus and $R$ sanguineus s.1.) across the sampling area.

The high number of ticks counted in this study is probably due to the large number of horses screened $(n=56)$, compared to cats and $\operatorname{dogs}(n=$ 30). It is known that ixodids are amongst the most common ectoparasites affecting animals, and that, in the case of horses, concomitant infestations by several tick species normally occur (Horak et al., 2017). Similarly, co-infestation by ticks and fleas in dogs is a frequent diagnostic finding, especially in tropical climatic areas where favorable conditions allow those arthropods to thrive (Kumsa et al., 2019). The absence of ticks in cats was expected since felids are rarely parasitized by ixodids. 


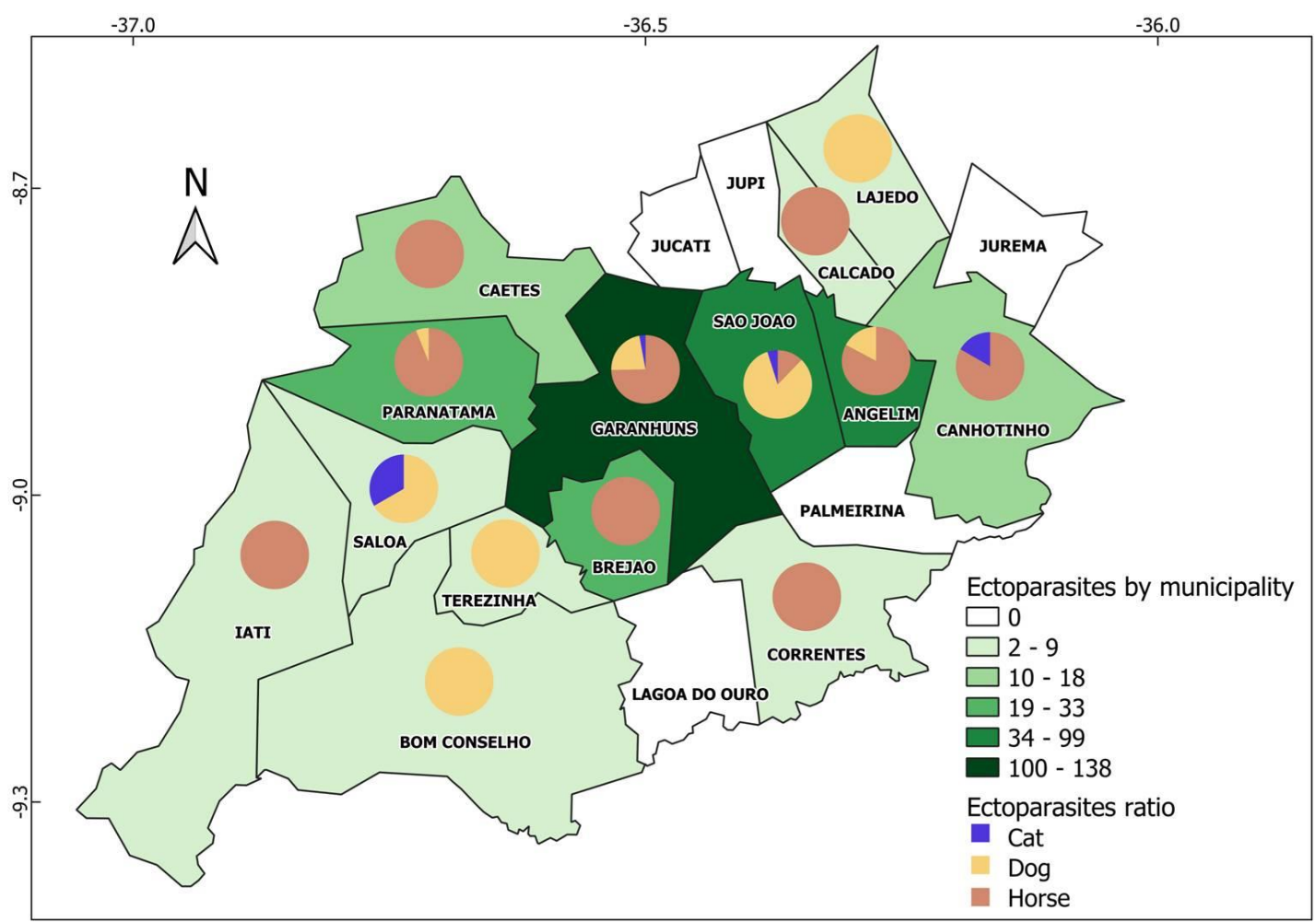

Figure 2. Distribution of fleas and ticks collected from cats, dogs and horses according to the study area.

Whether this due to the behavior of cats or to the low infestation pressure in the examined premises is hard to be defined, also taking into account to small number of cats enrolled (Dantas-Torres, 2009). Nonetheless, the majority of ticks collected on dogs and horses were adults $(\mathrm{n}=298)$ and only a small proportion were nymphs $(n=43)$. This finding could be explained for by the size of the adult stages instead of a lack in host preference. Indeed, nymphs of $R$. sanguineus s.l. and D. nitens preferentially feed on dogs and horses, respectively. Conversely, although the immature stages of A. sculptum show very low host specificity, horses are considered the preferential host.

From an epidemiological standpoint, the variety of ectoparasites herein reported is of great relevance due to the potential role that these hematophagous arthropods display in the transmission of several diseases. For instance, horses are frequently parasitized by A. sculptum, which represent the main tick species involved in the epidemiology of Spotted Fever in Brazil (Moraes-Filho, 2017). This species is widespread in different Brazilian biomes, included the
Caatinga biome (Moraes-Filho, 2017). Recently, phylogenetic studies have designated $A$. sculptum as member of the $A$. cajennense species complex, composed of five other species (Nava et al., 2014).

Dogs showed the highest variety of ectoparasites (up to four species) amongst the hosts herein enrolled. Besides the detection of ticks normally found on dogs (e.g., $R$. sanguineus), the occurrence of $A$. ovale deserves a special mentioning. It is known that this tick species is common in wild carnivores (Labruna et al., 2000) living in fragments of Atlantic Forest (MoraesFilho, 2017), thus suggesting that this ixodid species is shared between wild and domestic animals (Labruna et al., 2000), favoring the dispersion of pathogens. Interestingly, C. felis was found more in dogs than in cats.

This flea species has been observed in dogs and frequently overcomes the presence of $C$. canis in these animals (Slapeta et al., 2011). Most likely, the great ability of adaptation to different environmental conditions has been the key factor for the success of $C$. felis compared to other 
species (Slapeta et al., 2011). Although in this study a few number of cats was assessed, it is believed that dogs are more exposed than cats to ectoparasites, most likely the features of fur and the poor hygienic behavior presented by canids provide suitable conditions for the infestation and establishment of ectoparasites (Cañón-Franco and Pérez-Bedoya, 2010).

Data obtained in this study are pivotal to better know the species of ectoparasites infesting domestic animals (cats, dogs and horses) in this area, as well as to understand the potential risk that humans living in close contact with jeopardized animals. Some species herein reported are accounted as important vector of pathogens. For instance, $C$. felis has been important in the life cycle and transmission of the Rickettsia typhi and Rickettsia felis (Peniche-Lara et al., 2015), whereas A. sculptum is the most important vector of $R$. rickettsii to humans (Moraes-Filho, 2017). It is important to highlight that $A$. ovale is the main tick involved in transmission $R$. parkeri strain Atlantic rainforest (Moraes-Filho, 2017), and although until now in Brazil the role $R$. sanguineus as vector of $R$. rickettsii has not been fully elucidated, this tick species is a competent vector for this bacteria in Mexico and United States (Owen et al., 2019).

From a One Health perspective it is important to highlight that the study area presents suitable conditions for the emergence and re-emergence of vector-borne pathogens, since animals live in close contact with humans, anthropic actions has modified the natural environment, and some species of ectoparasites herein reported present a great ability as potential vector.

\section{CONCLUSION}

In conclusion, this study provides important information on the ectoparasites infesting domestic animals in this area. Therefore, preventive measures against these arthropods should be encouraged on the light of One Health perspective to reduce the threat of emerging and re-emerging pathogens.

\section{ACKNOWLEDGEMENTS}

This article is based on the Master dissertation (Postgraduate Program in Animal Bioscience), developed at the Federal Rural University of
Pernambuco, with support from a fellowship from Fundação de Amparo a Ciência e Tecnologia do Estado de Pernambuco (FACEPE). This study also integrates the universal project (420184/2016-3) entitled "Diversity of Ixodids and Sifonapters in company animals and its relationship with pathogens of importance in Public Health in the northeast region of Brazil", financed by Conselho Nacional de Desenvolvimento Científico e Tecnológico (CNPq).

\section{REFERENCES}

ARAGÃO, H.; FONSECA, F. Notas de ixodologia. VII. Lista e chave para os representantes da fauna ixodológica brasileira. Mem. Inst. Oswaldo Cruz, v.59, p.115-130, 1961.

AYRES, M.; AYRES, J.; AYRES D.L.; SANTOS, A.S. BioEstat 5.0: aplicações estatísticas nas áreas de ciências bio-médicas. Amazonas: Sociedade Civil Mamirauá, 2007. 380p.

BUSH, A.O.; LAFFERTY, K.D.; LOTZ, J.M.; SHOSTAK, A.W. Parasitology meets ecology on its own terms: margolis et al. revisited. J. Parasitol., v.83, p.575-583, 1997.

CAÑÓN-FRANCO, W.A.; PÉREZ-BEDOYA, J.L. Siphonaptera (Pulicidae) in dogs and cats of Colombia: clinical and epidemiological aspects. Vet. Parasitol., v.173, p.353-357, 2010.

CUNNINGHAM, A.A.; DASZAK, P.; WOOD, J.L.N. One health, emerging infectious diseases and wildlife: two decades of progress? Philos. Trans. Rev. Soc. Lond. B: Biol. Sci., v.372, p.20160167, 2017.

DANTAS-TORRES, F. Ticks on domestic animals in Pernambuco, Northeastern Brazil. Rev. Bras. Parasitol. Vet., v.18, p.22-28, 2009.

DANTAS-TORRES, F.; CAPELLI, G.; GIANNELLI, A. et al. Efficacy of an imidacloprid/flumethrin collar against fleas, ticks and tick-borne pathogens in dogs. Parasit. Vectors, v.6, p.1-8, 2013.

DANTAS-TORRES, F.; OTRANTO, D. Best practices for preventing vector-borne diseases in dogs and humans. Trends Parasitol., v.32, p.43-55, 2016.

DIGARD, J-P. Domestic biodiversity, a little-known aspect of animal biodiversity. Ann. Antropol., v.2, p.205-223, 2012.

ESCH, K.J.; PETERSEN, C.A. Transmission and epidemiology of zoonotic protozoal diseases of companion animals. Clin. Microbiol. Rev., v.26, p.5885, 2013. 
GONÇALVES, D.D.; MOURA, R.A.; DREER, M.K.P. et al. First record of Borrelia burgdorferi sensu lato antibodies in stray dogs in the Northwest Region of Parana State, Brazil. Semin. Ciênc. Agrár., v.36, p.2641-2648, 2015.

GUIMARÃES, J.H.; TUCCI, C.E.; BARROSBATTESTI, D.M. Ectoparasitos de importância veterinária. São Paulo: Plêide/FAPESP, 2001. 218p.

HORAK, I.G.; HEYNE, H.; HALAJIAN, A. et al. Parasites of domestic and wild animals in South Africa. L. Ixodid ticks infesting horses and donkeys. Onderstepoort J. Vet., v.84, p.1-6, 2017.

JENKS, G.F.; CASPALL, F.C. Error on choroplethic maps: definition, measurement, reduction. Ann. Assoc. Am. Geogr., v.61, p.217-244, 1971.

KRAUSE-PARELLO, C.A. Pet ownership and older women: the relationships among loneliness, pet attachment support, human social support, and depressed mood. J. Geriatr. Nurs., v.33, p.194-203, 2012.

KUMSA, B.; ABIY, Y.; ABUNNA, F. Ectoparasites infesting dogs and cats in Bishoftu, central Oromia, Ethiopia. Vet. Parasitol. Reg. Stud. Rep., v.15, p.1-6, 2019.

LABRUNA, M.B.; HOMEM, V.S.F.; HEINEMANN, M.B.; FERREIRA NETO, J.S. Ticks (Acari:Ixodidae) associated with rural dogs in Uruará, Eastern Amazon, Brazil. J. Med. Entomol., v.37, p.774-776, 2000.

LIMONGI, J.E.; SILVA, J.J.; PAULA, M.B.C.; MENTES, J. Aspectos epidemiológicos das infestações por sifonápteros na área urbana do município de Uberlândia, Minas Gerais, 2007-2010. Epidemiol. Serv. Saúde., v.22, p.285-294, 2013.

LINARDI, M.P.; GUIMARÃES, L.R. Sifonápteros do Brasil. São Paulo: Museu de Zoologia, 2000. 291p.

LINARDI, P.M. Checklist dos sifonápteros (insecta) do Estado do Mato Grosso, Brasil. Iheringia Sér. Zool., v.107, p.e2017148, 2017.

LIU, Y.; NORDONE, S.K.; YABSLEY, M.J. et al. Quantifying the relationship between human Lyme disease and Borrelia burgdorferi exposure in domestic dogs. Geoespat. Health, v.14, p.111-120, 2019.
MENCKE, N. Future challenges for parasitology: vector control and 'One health' in Europe: the veterinary medicinal view on CVBDs such as tick borreliosis, rickettsiosis and canine leishmaniosis. Vet. Parasitol., v.195, p.256-271, 2013.

MORAES-FILHO, J. Febre maculosa brasileira. Rev. Edu. Cont. Med. Vet. Zoo. CRMV-SP., v.15, p.38-45, 2017.

NAVA, S.; BEATI, L.; LABRUNA, M.B. et al. Reassessment of the taxonomic status of Amblyomma cajennense (Fabricius, 1787) with the description of three new species, Amblyomma tonelliae n. sp., Amblyomma interandinum n. sp. and Amblyomma patinoi n. sp., and reinstatement of Amblyomma mixtum Koch, 1844 and Amblyomma sculptum Berlese, 1888 (Ixodida: Ixodidae). Tick Tick-borne Dis., v.5, p.252276, 2014.

OWEN, H.; LISOWSKI, S.; SCHAEFER, C. et al. Variation in the geographic distribution and rickettsial infection rates of Rhipicephalus sanguineus contributes to the spread of RMSF in Arizona and Mexico. FASEB $J .$, v.33, p.662.48, 2019.

PACHECO, R.R.; MORAES-FILHO, J.; GUEDES, E. et al. Rickettsial infections of dogs, horses and ticks in Juiz de Fora, southeastern Brazil, and isolation of Rickettsia rickettsii from Rhipicephalus sanguineus ticks. Med. Vet. Entomol., v.25, p.148-155, 2011.

PENICHE-LARA, G.; DZUL-ROSADO, K.; PÉREZOSORIO, C.Y.; ZAVALA-CASTRO, J. Rickettsia typhi in rodents and R. felis in fleas in Yucatán as a possible causal agent of undefined febrile cases. Rev. Inst. Med. Trop. SP., v.57, p.129-132, 2015.

SLAPETA, J.; KING, J.; MCDONELL, D. et al. The cat flea (Ctenocephalides f. felis) is the dominant flea on domestic dogs and cats in Australian veterinary practices. Vet. Parasitol., v.180, p.383-388, 2011.

TROTTA, M.; NICETTO, M.; FOGLIAZZA, A. et al. Detection of Leishmania infantum, Babesia canis, and rickettsiae in ticks removed from dogs living in Italy. Tick Tick Borne Dis., v.6, p.294-297, 2012.

ZIMMERMANN, N.P.; AGUIRRE, A.A.R.; RODRIGUES, V.S. et al. Wildlife species, Ixodid fauna and new host records for ticks in an Amazon forest area, Rondônia, Brazil. Rev. Bras. Parasitol. Vet., v.27, p.177-182, 2018. 